\title{
Effect of temperature, humidity and soil pH on development of Plasmodiophora brassicae
}

\author{
Wpływ temperatury, wilgotności i pH gleby na rozwój \\ Plasmodiophora brassicae
}

\author{
Ewa Jajor ${ }^{1 *}$, Jan Bocianowski ${ }^{2}$, Ilona Świerczyńska ${ }^{1}$, Katarzyna Pieczul $^{1}$, \\ Joanna Horoszkiewicz-Janka ${ }^{1}$, Marek Korbas ${ }^{1}$
}

\begin{abstract}
Summary
Plasmodiophora brassicae is a pathogen that causes clubroot - one of the most serious and economically most important diseases of the Brassica family. Development of $P$. brassicae is influenced by factors such as temperature, humidity and soil $\mathrm{pH}$. The effect of these factors may vary due to the adaptability of $P$. brassicae and unequal degree of resistance of plants to infection. The aim of the study was to determine the effect of temperature, humidity and soil $\mathrm{pH}$ on $P$. brassicae infection of plants susceptible to infection and plants with increased resistance. The experiment included three $\mathrm{pH}$ ranges of the substrate, 3 humidity variants and 4 temperature ranges. The study revealed that the development of $P$. brassicae was limited the most by the lowest temperature $\left(13^{\circ} \mathrm{C}\right)$ and low humidity of the substrate, while high temperature and excess humidity showed the most stimulating effect on the pathogen. The optimum temperature for the development of the disease on sensitive varieties was $20-24^{\circ} \mathrm{C}$, while on varieties with increased resistance $16-20^{\circ} \mathrm{C}$.
\end{abstract}

Key words: Plasmodiophora brassicae, soil pH, temperature, humidity

\section{Streszczenie}

Plasmodiophora brassicae to patogen powodujący kiłę kapusty - jedną z najgroźniejszych i najważniejszych ekonomicznie chorób roślin z rodziny kapustowatych. Na jego rozwój wpływają m.in. takie czynniki, jak: temperatura, wilgotność oraz pH gleby. Działanie wymienionych czynników może się zmieniać w związku ze zdolnościami adaptacyjnymi $P$. brassicae oraz niejednakowym stopniem odporności uprawianych odmian. Celem pracy było określenie wpływu temperatury, wilgotności oraz pH podłoża na porażenie przez P. brassicae roślin wrażliwych na infekcję oraz roślin o podwyższonej odporności. W doświadczeniach uwzględniono trzy zakresy pH podłoża, 3 warianty wilgotności oraz 4 zakresy temperatur. Doświadczenia wykazały, że rozwój $P$. brassicae najbardziej ograniczała najniższa temperatura $\left(13^{\circ} \mathrm{C}\right)$ oraz niska wilgotność podłoża, natomiast najbardziej stymulująco na patogena wpływała wysoka temperatura oraz wysoka wilgotność. Optymalna dla rozwoju choroby na odmianach wrażliwych była temperatura $20-24^{\circ} \mathrm{C}$, natomiast na odmianach o podwyższonej odporności $16-20^{\circ} \mathrm{C}$.

Słowa kluczowe: Plasmodiophora brassicae, pH podłoża, temperatura, wilgotność

\footnotetext{
Instytut Ochrony Roślin - Państwowy Instytut Badawczy

Władysława Węgorka 20, 60-318 Poznań

${ }^{2}$ Uniwersytet Przyrodniczy w Poznaniu

Wojska Polskiego 28, 60-637 Poznań

*corresponding author: e.jajor@iorpib.poznan.pl

ORCID: 0000-0002-4412-1766
} 


\section{Wstęp / Introduction}

Plasmodiophora brassicae to patogen powodujący kiłę kapusty - jedną z najgroźniejszych oraz najważniejszych ekonomicznie chorób roślin $\mathrm{z}$ rodziny kapustowatych (Korbas i Jajor 2013). Jest szeroko rozpowszechniony na całym świecie szczególnie na obszarach o umiarkowanym i wilgotnym klimacie. Według danych EPPO z 2017 roku P. brassicae występuje na sześciu kontynentach: w Afryce, Ameryce Północnej i Południowej, Azji, Europie oraz Oceanii.

W Polsce $P$. brassicae stanowi poważny problem przede wszystkim w uprawach rzepaku (Korbas i wsp. 2009). Szacuje się, że na około 250 tys. ha w naszym kraju, gdzie uprawiany jest rzepak, w glebie znajdują się zarodniki tego patogena (Konieczny 2012). Kiła kapusty spotykana jest w wielu regionach Polski, jednak nasilenie jej występowania jest bardzo zróżnicowane. W związku z brakiem skutecznej metody chemicznej do zwalczania tej choroby, szczególne znaczenie ma uprawa odmian o podwyższonej odporności na porażenie przez patogena.

Badania wpływu warunków środowiska na rozwój P. brassicae wskazują, że najistotniejsze są wartości temperatury, wilgotności oraz pH gleby (Rod 1996; Dixon 2009). W optymalnych warunkach już 1 zarodnik w $10 \mathrm{~g}$ gleby wystarczy do zainfekowania rośliny (Rod 1996; Rennie i wsp. 2011). Działanie wymienionych czynników może być zmienne w związku ze zdolnościami adaptacyjnymi $P$. brassicae oraz niejednakowym stopniem odporności roślin.

Celem pracy było określenie wpływu temperatury, wilgotności oraz $\mathrm{pH}$ podłoża na porażenie przez $P$. brassicae roślin wrażliwych na infekcję oraz roślin o podwyższonej odporności.

\section{Materiały i metody / Materials and methods}

Doświadczenia przeprowadzono w kabinach szklarniowych o ściśle kontrolowanych warunkach przy fotoperiodzie 14 godz. światła/10 godz. ciemności. Doniczkopalety wypełniono podłożem do uprawy roślin o 3 wartościach pH: 3,5-4,5; 5,0-5,5; 6,0-6,5. Do doniczek wysiewano 20 nasion (po 5 nasion do pojedynczej komory w doniczkopalecie) 2 gatunków roślin z rodziny kapustowatych:

- rzepak (Brassica napus), odmiany o podwyższonej odporności na porażenie przez patogena: Alister, Mendel oraz odmiany wrażliwe na porażenie przez patogena: Poznaniak, Pamela,

- gorczyca biała (Sinapis alba), odmiana: Bamberka, popularna roślina poplonowa.

Po pięciu dniach od wysiewu nasion przygotowywano zawiesinę zarodników przetrwalnikowych do inokulacji. Materiał przeznaczony do sporządzenia inokulum pochodził z terenu województwa zachodniopomorskiego. W rejonie tym zaobserwowano przełamanie odporności uprawianych odmian, co jest wynikiem dużej zmienności genetycznej P. brassicae (К̌ičařová i wsp. 2016). Rozwinięte narośla korzeniowe dokładnie homogenizowano za pomocą blendera, następnie filtrowano przez kilkuwarstwową gazę oraz rozcieńczano w celu uzyskania pożądanego stężenia. Zagęszczenie zarodników w uzyskanym inokulacie obliczano za pomocą komory zliczeniowej według Neubauerimproved o głębokości 0,1 mm (Marienfeld-Superior) pod mikroskopem optycznym. Wykiełkowane rośliny inokulowano zawiesiną o stężeniu $1 \times 10^{7}$ zarodników/ml (po $40 \mathrm{ml}$ zawiesiny do każdej komory w doniczkopalecie). Doświadczenia przeprowadzono w dwóch seriach, każdorazowo po 4 powtórzenia.

Rośliny były podlewane co 4-5 dni w trzech objętościach wody na pojedynczą komorę w doniczkopalecie:

- $50 \mathrm{ml}$ wody - wariant nadmiaru wody,

- $40 \mathrm{ml}$ wody - wariant optymalny dla roślin w danej temperaturze,

- $30 \mathrm{ml}$ wody - wariant niedoboru wody.

Powyższe warianty wody zostały wyznaczone na podstawie doświadczenia umożliwiającego wskazanie, która objętość wody przy danym rodzaju podłoża pozwala na uzyskanie nadmiaru wody w doniczce, na jej optymalną zawartość oraz niedobór.

Doświadczenia wykonano w temperaturach:

- $13^{\circ} \mathrm{C}$ przez całą dobę,

- $18^{\circ} \mathrm{C}$ w dzień $/ 14^{\circ} \mathrm{C}$ w nocy,

- $20^{\circ} \mathrm{C} \mathrm{w} \mathrm{dzień} / 16^{\circ} \mathrm{C}$ w nocy,

- $24^{\circ} \mathrm{C}$ w dzień $/ 20^{\circ} \mathrm{C}$ w nocy.

Stopień porażenia roślin oceniano po 6 tygodniach w 4-stopniowej skali (Vigier i wsp. 1989), gdzie:

0 - oznacza roślinę o zdrowym systemie korzeniowym,

1 - niewielkie guzy na korzeniach bocznych (1 do $10 \%$,

2 - objawy porażenia występują na 11 do 50\% systemu korzeniowego,

3 - objawy porażenia występują na 51 do $100 \%$ systemu korzeniowego.

Z uzyskanych wyników obliczono procent porażonych roślin oraz indeks porażenia (ID) według wzoru (Strelkov i wsp. 2006):

$$
\mathrm{ID}=\left(0 \mathrm{n}_{0}+1 \mathrm{n}_{1}+2 \mathrm{n}_{2}+3 \mathrm{n}_{3}\right) \times 100 / 3 \mathrm{~N}_{\mathrm{t}},
$$

gdzie: $\mathrm{n}_{0}-\mathrm{n}_{3}-$ liczba roślin porażonych $\mathrm{w}$ danym stopniu, $\mathrm{N}_{\mathrm{t}}$ - całkowita liczba badanych roślin.

Normalność rozkładu obserwowanej cechy testowano z użyciem testu normalności Shapiro-Wilka (Shapiro i Wilk 1965). Czteroczynnikowa analiza wariancji (ANOVA) została przeprowadzona w celu weryfikacji hipotez zerowych o brak wpływu wilgotności, $\mathrm{pH}$, odmiany i temperatury oraz weryfikacji hipotez o brak wpływu interakcji 
podwójnych, potrójnych i poczwórnej na zmienność obserwowanej cechy.

\section{Wyniki i dyskusja / Results and discussion}

Odmiany odporne na porażenie przez $P$. brassicae charakteryzuje zdolność hamowania rozwoju patogena wewnątrz rośliny, a zatem komórki korzenia zostają porażone, jednak nie obserwuje się powstania objawów choroby oraz nie dochodzi do wytworzenia zarodników przetrwalnikowych (Hwang i wsp. 2012). Badania prowadzone na odpornych oraz wrażliwych odmianach rzepaku wykazały, że plazmodia $P$. brassicae powstające w korzeniach odmian o podwyższonej odporności posiadają znacznie mniej jąder i ostatecznie nie dojrzewają (Hwang i wsp. 2011). Związane jest to z obecnością genu lub genów odporności warunkujących odpowiedź komórek rośliny (Crute i wsp. 1980; Voorrips 1996).

Odporność obecnie dostępnych na rynku odmian nie jest całkowita i zależy od wielu czynników. Potwierdzają to wyniki przeprowadzonych doświadczeń, w których we wszystkich badanych wariantach testu biologicznego obserwowano rośliny $\mathrm{z}$ objawami kiły kapusty. Liczba porażonych roślin oraz stopień ich porażenia zależał od zastosowanej wilgotności, wartości $\mathrm{pH}$, temperatury oraz gatunku/odmiany rośliny (tab. 1).

Wyniki przeprowadzonej analizy wariancji (ANOVA) wykazały istotny statystycznie wpływ wszystkich badanych czynników na wartości indeksu porażenia (tab. 2). Istotny statystycznie wpływ na wartości obserwowanej cechy miały wszystkie interakcje, oprócz: wilgotność $\times \mathrm{pH}, \mathrm{pH} \times$ odmiana, wilgotność $\times \mathrm{pH} \times$ odmiana oraz wilgotność $\times \mathrm{pH}$ $\times$ odmiana $\times$ temperatura (tab. 2 ).

Wykresy pudełkowe rozkładu wartości indeksu porażenia wykonane dla poszczególnych gatunków oraz odmian badanych roślin, obrazują różnice w wartościach ID, które potwierdziły wrażliwość badanych roślin rzepaku odmian Poznaniak i Pamela oraz gorczycy (odmiana Bamberka), jak również podwyższoną odporność rzepaku odmian Alister i Mendel (rys. 1).

Rośliny podatne na porażenie $P$. brassicae: gorczyca biała oraz rzepak odmiany Poznaniak oraz Pamela charakteryzowały się szerokim zakresem ID od 0 do 100\%, jednak najczęściej indeks porażenia przekraczał wartość 40\% w przypadku rzepaku odmiany Poznaniak, 55\% dla rzepaku odmiany Pamela oraz 65\% dla gorczycy białej. Najbardziej podatną na porażenie przez P. brassicae rośliną była gorczyca biała, w przypadku której ponad połowa uzyskanych wartości ID przekraczała 90\%. Odmiany

Tabela 1. Średni indeks porażenia roślin (ID) oraz odchylenie standardowe w poszczególnych wariantach testu biologicznego Table 1. Average index of disease (ID) and standard deviation in individual variants of the biological test

\begin{tabular}{|c|c|c|c|c|c|c|c|c|c|c|}
\hline \multirow{3}{*}{ 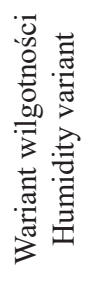 } & \multirow{3}{*}{ 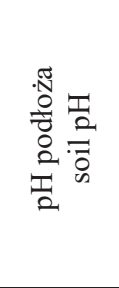 } & \multirow{3}{*}{ 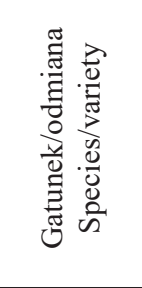 } & \multicolumn{8}{|c|}{ Zakres temperatur - Temperature range } \\
\hline & & & \multicolumn{2}{|r|}{$13^{\circ} \mathrm{C}$} & \multicolumn{2}{|c|}{$14-18^{\circ} \mathrm{C}$} & \multicolumn{2}{|c|}{$16-20^{\circ} \mathrm{C}$} & \multicolumn{2}{|c|}{$20-24^{\circ} \mathrm{C}$} \\
\hline & & & $\begin{array}{c}\text { ID } \\
{[\%]}\end{array}$ & $\begin{array}{c}\text { odchylenie } \\
\text { standardowe } \\
\text { standard } \\
\text { deviation }\end{array}$ & $\begin{array}{c}\text { ID } \\
{[\%]}\end{array}$ & $\begin{array}{l}\text { odchylenie } \\
\text { standardowe } \\
\text { standard } \\
\text { deviation }\end{array}$ & $\begin{array}{c}\text { ID } \\
{[\%]}\end{array}$ & $\begin{array}{c}\text { odchylenie } \\
\text { standardowe } \\
\text { standard } \\
\text { deviation }\end{array}$ & $\begin{array}{l}\text { ID } \\
{[\%]}\end{array}$ & $\begin{array}{c}\text { odchylenie } \\
\text { standardowe } \\
\text { standard } \\
\text { deviation }\end{array}$ \\
\hline 1 & 2 & 3 & 4 & 4 & 6 & 7 & 8 & 9 & 10 & 11 \\
\hline \multirow{15}{*}{$30 \mathrm{ml}$} & \multirow{5}{*}{$3,5-4,5$} & Alister & 0,78 & 1,386 & 21,21 & 22,499 & 37,50 & 12,720 & 23,19 & 0,181 \\
\hline & & Mendel & 2,90 & 5,893 & 19,88 & 26,364 & 39,29 & 35,418 & 41,18 & 17,350 \\
\hline & & Poznaniak & 2,86 & 2,555 & 42,71 & 8,995 & 34,31 & 17,142 & 64,10 & 18,267 \\
\hline & & Pamela & 3,30 & 4,660 & 69,57 & 30,936 & 90,20 & 1,964 & 83,33 & 13,775 \\
\hline & & Gorczyca & 33,33 & 11,785 & 42,86 & 44,194 & 90,20 & 1,964 & 100,00 & 0 \\
\hline & \multirow{5}{*}{$5,0-5,5$} & Alister & 3,42 & 2,543 & 48,89 & 4,835 & 40,58 & 24,295 & 28,89 & 2,346 \\
\hline & & Mendel & 2,63 & 5,051 & 38,57 & 3,990 & 20,83 & 7,071 & 36,36 & 2,143 \\
\hline & & Poznaniak & 9,52 & 0,556 & 66,67 & 4,005 & 36,17 & 11,828 & 71,54 & 4,770 \\
\hline & & Pamela & 20,51 & 16,189 & 79,71 & 6,547 & 91,67 & 3,571 & 83,33 & 7,464 \\
\hline & & Gorczyca & 76,19 & 1,964 & 69,37 & 19,070 & 72,73 & 18,407 & 100,00 & 0 \\
\hline & \multirow{5}{*}{$6,0-6,5$} & Alister & 3,03 & 3,286 & 23,81 & 17,980 & 46,03 & 12,642 & 27,78 & 11,575 \\
\hline & & Mendel & 4,55 & 5,439 & 8,06 & 7,767 & 41,27 & 29,010 & 30,43 & 2,050 \\
\hline & & Poznaniak & 2,02 & 3,143 & 36,94 & 10,289 & 76,92 & 6,547 & 52,85 & 2,058 \\
\hline & & Pamela & 4,63 & 5,619 & 51,28 & 28,284 & 47,44 & 7,241 & 83,33 & 6,285 \\
\hline & & Gorczyca & 37,04 & 26,937 & 47,31 & 2,562 & 87,65 & 12,405 & 94,44 & 5,893 \\
\hline
\end{tabular}


Tabela 1. Średni indeks porażenia roślin (ID) oraz odchylenie standardowe w poszczególnych wariantach testu biologicznego - cd. Table 1. Average index of disease (ID) and standard deviation in individual variants of the biological test - continued

\begin{tabular}{|c|c|c|c|c|c|c|c|c|c|c|}
\hline 1 & 2 & 3 & 4 & 4 & 6 & 7 & 8 & 9 & 10 & 11 \\
\hline \multirow{15}{*}{$40 \mathrm{ml}$} & \multirow{5}{*}{$3,5-4,5$} & Alister & 5,13 & 4,285 & 53,47 & 20,302 & 52,56 & 28,427 & 31,53 & 2,773 \\
\hline & & Mendel & 7,58 & 14,240 & 32,76 & 5,836 & 68,18 & 2,619 & 26,09 & 11,996 \\
\hline & & Poznaniak & 4,94 & 7,857 & 82,91 & 11,785 & 65,87 & 1,071 & 81,90 & 15,559 \\
\hline & & Pamela & 22,92 & 10,607 & 60,87 & 10,733 & 100,00 & 0 & 65,00 & 7,857 \\
\hline & & Gorczyca & 44,44 & 47,140 & 95,83 & 10,102 & 91,67 & 5,143 & 100,00 & 0 \\
\hline & \multirow{5}{*}{$5,0-5,5$} & Alister & 1,75 & 1,684 & 49,44 & 0,419 & 68,12 & 10,153 & 45,16 & 4,027 \\
\hline & & Mendel & 10,75 & 2,306 & 47,11 & 10,371 & 76,92 & 6,173 & 35,56 & 1,414 \\
\hline & & Poznaniak & 33,33 & 3,286 & 88,48 & 3,468 & 80,95 & 3,536 & 82,31 & 9,114 \\
\hline & & Pamela & 75,00 & 13,499 & 87,42 & 9,933 & 97,78 & 2,143 & 85,00 & 0,238 \\
\hline & & Gorczyca & 91,67 & 7,857 & 89,90 & 9,821 & 98,77 & 1,309 & 96,97 & 2,619 \\
\hline & \multirow{5}{*}{$6,0-6,5$} & Alister & 4,50 & 4,367 & 44,64 & 14,273 & 26,98 & 3,274 & 29,63 & 8,547 \\
\hline & & Mendel & 6,90 & 1,733 & 26,44 & 12,715 & 56,41 & 12,066 & 30,00 & 1,263 \\
\hline & & Poznaniak & 31,75 & 17,892 & 74,47 & 28,192 & 52,63 & 2,481 & 77,42 & 1,486 \\
\hline & & Pamela & 63,49 & 19,258 & 61,36 & 45,766 & 86,67 & 14,142 & 91,03 & 0,842 \\
\hline & & Gorczyca & 79,17 & 19,642 & 60,49 & 23,016 & 90,80 & 5,213 & 96,67 & 3,928 \\
\hline \multirow{15}{*}{$50 \mathrm{ml}$} & \multirow{5}{*}{$3,5-4,5$} & Alister & 1,96 & 2,946 & 30,21 & 1,756 & 42,22 & 15,713 & 28,57 & 11,785 \\
\hline & & Mendel & 2,67 & 4,714 & 29,06 & 13,150 & 61,40 & 13,928 & 21,90 & 5,636 \\
\hline & & Poznaniak & 7,41 & 3,256 & 93,10 & 10,102 & 69,77 & 8,374 & 79,49 & 17,142 \\
\hline & & Pamela & 12,72 & 10,002 & 94,44 & 2,619 & 100,00 & 0 & 82,46 & 1,684 \\
\hline & & Gorczyca & 33,33 & 23,570 & 44,93 & 30,641 & 93,33 & 8,418 & 100,00 & 0 \\
\hline & \multirow{5}{*}{$5,0-5,5$} & Alister & 10,00 & 4,714 & 65,15 & 4,664 & 78,33 & 13,571 & 25,29 & 2,020 \\
\hline & & Mendel & 22,58 & 18,106 & 37,95 & 36,665 & 80,70 & 0,820 & 17,61 & 0,576 \\
\hline & & Poznaniak & 56,76 & 16,196 & 89,33 & 9,428 & 75,21 & 8,949 & 80,18 & 2,842 \\
\hline & & Pamela & 86,46 & 10,630 & 88,89 & 1,894 & 96,67 & 4,285 & 93,10 & 7,071 \\
\hline & & Gorczyca & 100,00 & 0 & 86,11 & 9,560 & 98,81 & 1,241 & 100,00 & 0 \\
\hline & \multirow{5}{*}{$6,0-6,5$} & Alister & 15,05 & 14,163 & 20,00 & 18,036 & 58,67 & 8,008 & 13,89 & 8,755 \\
\hline & & Mendel & 9,68 & 0,705 & 29,46 & 23,788 & 58,02 & 3,143 & 12,96 & 5,833 \\
\hline & & Poznaniak & 56,25 & 20,624 & 72,22 & 8,929 & 65,04 & 11,561 & 78,43 & 14,895 \\
\hline & & Pamela & 82,29 & 5,893 & 53,54 & 12,305 & 100,00 & 0 & 81,61 & 5,752 \\
\hline & & Gorczyca & 93,33 & 5,893 & 57,78 & 3,158 & 92,06 & 11,785 & 100,00 & 0 \\
\hline
\end{tabular}

rzepaku o podwyższonej odporności (Alister oraz Mendel) wykazały mniejszy zakres rozkładu ID, który w żadnym wariancie testu biologicznego nie przekroczył wartości 80\% (Mendel) oraz 90\% (Alister). Większą odpornością charakteryzowały się rośliny rzepaku odmiany Mendel, w której indeks porażenia najczęściej nie przekraczał 40\% (rys. 1).

Jednym z czynników wpływających na porażanie roślin przez P. brassicae jest pH. Środowisko zasadowe hamuje infekcje włośników, jak również opóźnia dojrzewanie plazmodiów oraz formowanie narośli na korzeniach (Palm 1958; Webster i Dixon 1991). Badania wykazują, że wysokie stężenie jonów wapnia w pH 6,2-7,2 istotnie zmniejsza liczbę infekcji i spowalnia rozwój patogena, natomiast wyższe stężenia całkowicie hamują dalsze etapy rozwoju P. brassicae, nawet mimo dużej zawartości zarodników w glebie (Karling 1942; Colhoun 1958; Dixon 2009).
Przeprowadzone doświadczenia nie wykazały znaczącego wpływu tego czynnika na rozwój choroby. Analiza rozkładu wartości ID ze względu na pH podłoża (rys. 2A) wykazała niewielkie różnice pomiędzy badanymi wariantami. W przypadku podłoża o $\mathrm{pH}$ w zakresach 3,5-4,5 oraz 6,0-6,5 rozkład wartości indeksu porażenia roślin był bardzo równomierny, natomiast przy $\mathrm{pH}$ 5,0-5,5 połowa uzyskanych wartości ID przekraczała $70 \%$.

Temperatura otoczenia wpływa na proces porażania włośników przez zarodniki pływkowe oraz rozwój plazmodium w drugim tygodniu infekcji (Rod 1996). Według Wellman (1930) kiła kapusty najlepiej rozwija się w temperaturach $18-24^{\circ} \mathrm{C}$, natomiast jej rozwój zostaje zahamowany poniżej $12^{\circ} \mathrm{C}$ oraz powyżej $27^{\circ} \mathrm{C}$. Wykresy pudełkowe rozkładu wartości ID ze względu na zastosowaną temperaturę hodowli (rys. 2B) wskazują, że największy hamujący wpływ na porażenie roślin miała 
Tabela 2. Wyniki analizy wariancji (ANOVA)

Table 2. Results of analysis of variance (ANOVA)

\begin{tabular}{|c|c|c|c|c|c|}
\hline $\begin{array}{l}\text { Źródło zmienności } \\
\text { Source of variation }\end{array}$ & d.f. & $\begin{array}{l}\text { Suma kwadratów } \\
\text { Sum of squares }\end{array}$ & $\begin{array}{l}\text { Średni kwadrat } \\
\text { Mean square }\end{array}$ & $\begin{array}{l}\text { Statystyka F } \\
\text { F-statistic }\end{array}$ & $\begin{array}{l}\text { p-wartość } \\
\text { p-value }\end{array}$ \\
\hline Wilgotność - Humidity & 2 & 16478,2 & 8239,1 & 46,92 & $<0,001$ \\
\hline $\mathrm{pH}-$ Soil $\mathrm{pH}$ & 2 & 11319,9 & 5659,9 & 32,23 & $<0,001$ \\
\hline Odmiana - Variety & 4 & 154192,5 & 38548,1 & 219,50 & $<0,001$ \\
\hline Temperatura - Temperature & 3 & 85440,3 & 28480,1 & 162,17 & $<0,001$ \\
\hline $\begin{array}{l}\text { Wilgotność } \times \mathrm{pH} \\
\text { Humidity } \times \text { soil pH }\end{array}$ & 4 & 1359,2 & 339,8 & 1,93 & 0,107 \\
\hline $\begin{array}{l}\text { Wilgotność } \times \text { odmiana } \\
\text { Humidity } \times \text { variety }\end{array}$ & 8 & 4410,9 & 551,4 & 3,14 & 0,002 \\
\hline $\begin{array}{l}\mathrm{pH} \times \text { odmiana } \\
\text { Soil } \mathrm{pH} \times \text { variety }\end{array}$ & 8 & 2054,8 & 256,8 & 1,46 & 0,174 \\
\hline $\begin{array}{l}\text { Wilgotność } \times \text { temperatura } \\
\text { Humidity } \times \text { temperature }\end{array}$ & 6 & 6274,9 & 1045,8 & 5,96 & $<0,001$ \\
\hline $\begin{array}{l}\mathrm{pH} \times \text { temperatura } \\
\text { Soil } \mathrm{pH} \times \text { temperature }\end{array}$ & 6 & 12386,3 & 2064,4 & 11,75 & $<0,001$ \\
\hline $\begin{array}{l}\text { Odmiana } \times \text { temperatura } \\
\text { Variety } \times \text { temperature }\end{array}$ & 12 & 28662,3 & 2388,5 & 13,60 & $<0,001$ \\
\hline $\begin{array}{l}\text { Wilgotność } \times \mathrm{pH} \times \text { odmiana } \\
\text { Humidity } \times \text { soil } \mathrm{pH} \times \text { variety }\end{array}$ & 16 & 2691,5 & 168,2 & 0,96 & 0,505 \\
\hline $\begin{array}{l}\text { Wilgotność } \times \mathrm{pH} \times \text { temperatura } \\
\text { Humidity } \times \text { soil } \mathrm{pH} \times \text { temperature }\end{array}$ & 12 & 5723,0 & 476,9 & 2,72 & 0,002 \\
\hline $\begin{array}{l}\text { Wilgotność } \times \text { odmiana } \times \text { temperatura } \\
\text { Humidity } \times \text { variety } \times \text { temperature }\end{array}$ & 24 & 8807,1 & 367,0 & 2,09 & 0,003 \\
\hline $\begin{array}{l}\mathrm{pH} \times \text { odmiana } \times \text { temperatura } \\
\text { Soil } \mathrm{pH} \times \text { variety } \times \text { temperature }\end{array}$ & 24 & 9230,0 & 384,6 & 2,19 & 0,002 \\
\hline $\begin{array}{l}\text { Wilgotność } \times \mathrm{pH} \times \text { odmiana } \times \text { temperatura } \\
\text { Humidity } \times \text { soil } \mathrm{pH} \times \text { variety } \times \text { temperature }\end{array}$ & 48 & 9928,3 & 206,8 & 1,18 & 0,222 \\
\hline Błąd - Residual & 180 & 31611,1 & 175,6 & - & - \\
\hline Całość - Total & 359 & 390570,0 & - & - & - \\
\hline
\end{tabular}

d.f. - liczba stopni swobody - number of degrees of freedom

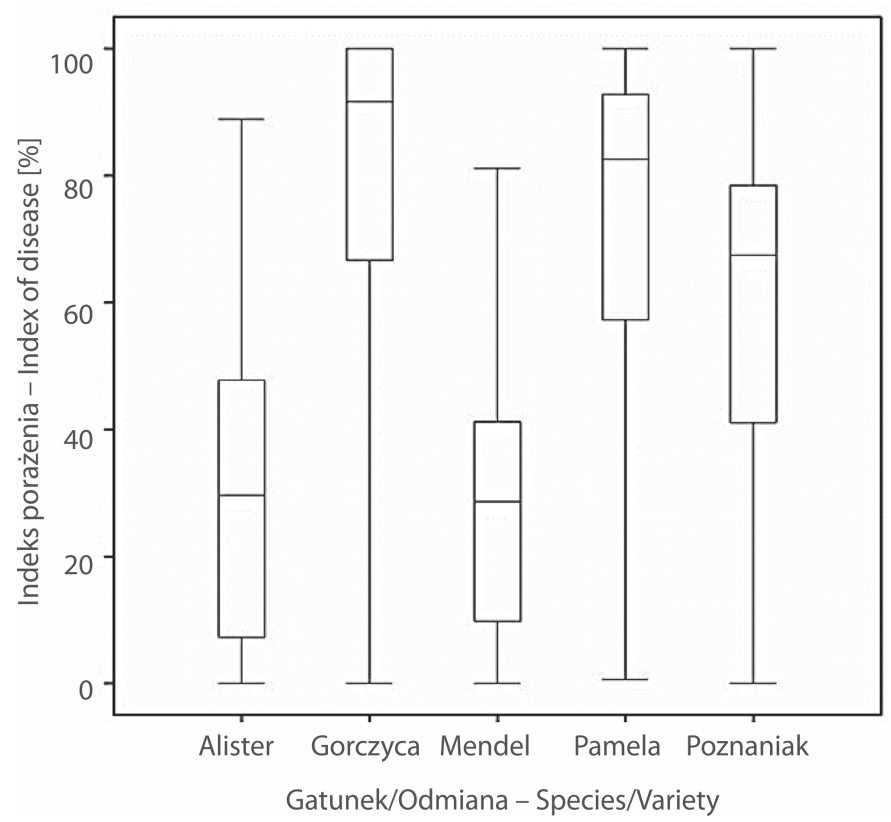

Rys. 1. Rozkład wartości indeksu porażenia (ID) dla poszczególnych gatunków/odmian badanych roślin dla obu serii doświadczeń

Fig. 1. Distribution of index disease (ID) values for individual species/varieties of tested plants for both series of experiments 
A

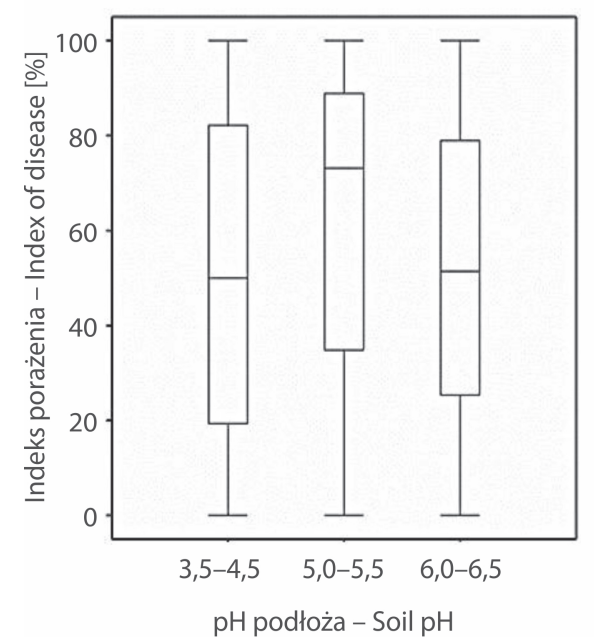

B

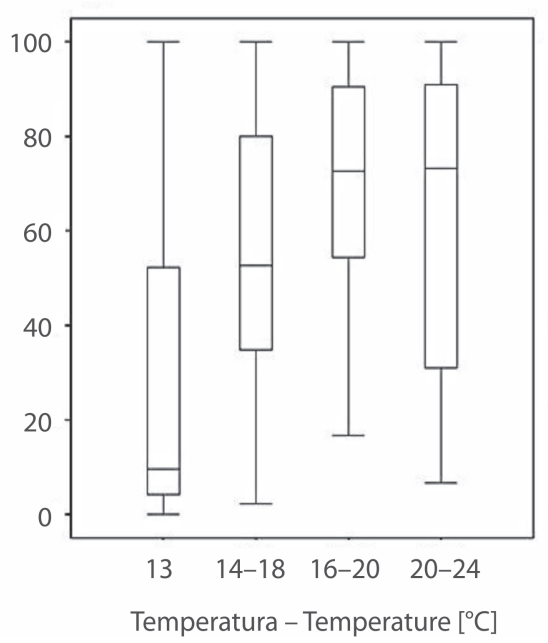

C

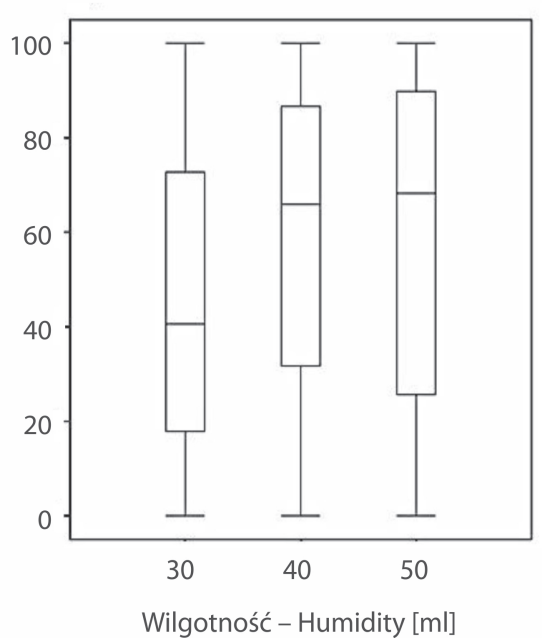

Rys. 2. Rozkład wartości indeksu porażenia (ID) dla poszczególnych wariantów: A - pH podłoża, B - temperatury, C - wilgotności podłoża dla obu serii doświadczeń

Fig. 2. Distribution of index disease (ID) values for individual variants: $\mathrm{A}$ - substrate $\mathrm{pH}, \mathrm{B}$ - temperature, $\mathrm{C}$ - substrate moisture content for both series of experiments

najniższa analizowana temperatura $\left(13^{\circ} \mathrm{C}\right)$, w której połowa uzyskanych wartości ID nie przekroczyła 10\%. W pozostałych zakresach temperatur uzyskane wartości ID były znacznie wyższe. Najbardziej stymulująco na patogena działały temperatury $\mathrm{w}$ przedziałach: $16-20^{\circ} \mathrm{C}$ oraz $20-24^{\circ} \mathrm{C}$. W obu przypadkach połowa uzyskanych wartości indeksu porażenia przekraczała 70\%. Potwierdzają to również badania Gossen i wsp. (2012), których wyniki wskazują, że w przypadku rzepaku optymalna temperatura zawiera się $\mathrm{w}$ przedziale $23-26^{\circ} \mathrm{C}$, natomiast poniżej $17^{\circ} \mathrm{C}$ i powyżej $26^{\circ} \mathrm{C}$ efektywność infekcyjna $P$. brassicae jest zdecydowanie niższa.

Obecność wody w glebie jest niezbędna w procesie przemieszczania się zarodników pływkowych (Karling 1968), jednak zbyt wysoka wilgotność powoduje zahamowanie infekcji, ponieważ kiełkowanie zarodników P. brassicae wymaga warunków tlenowych (Rod 1996). W przeprowadzonych badaniach najniższe wartości indeksu porażenia obserwowano w wariancie niedoboru wody, w którym rośliny podlewane były objętością $30 \mathrm{ml}$ (rys. 2C). Połowa uzyskanych wyników ID w tej wersji testu biologicznego nie przekroczyła wartości 40\%. Wyniki uzyskane w wariantach optymalnego podlewania $(40 \mathrm{ml})$ oraz nadmiaru wody $(50 \mathrm{ml})$ były do siebie zbliżone.

Optymalna temperatura dla rozwoju $P$. brassicae uzależniona jest od regionu geograficznego, gatunku porażanej rośliny, czy panujących warunków środowiskowych (Dixon 2009). Potwierdzają to również przedstawione w niniejszej pracy wyniki. Porównanie wykresów pudełkowych rozkładu wartości ID odrębnie dla roślin wrażliwych oraz roślin o podwyższonej odporności ze względu na temperaturę wykazało znaczące różnice pomiędzy badanymi obiektami (rys. 3). Rośliny wrażliwe na porażenie przez P. brassicae: gorczyca biała oraz rzepak odmiany Poznaniak i Pamela charakteryzowały się wysokimi wartościami indeksu porażenia. Rozkład wartości ID tych roślin w najniższej temperaturze $\left(13^{\circ} \mathrm{C}\right)$ miał szeroki zakres, obejmujący przedział od 0 do $100 \%$. Zakres wartości indeksu porażenia zmniejszał się wraz ze wzrostem temperatury. W najwyższej badanej temperaturze $\left(20-24^{\circ} \mathrm{C}\right)$ wszystkie uzyskane wartości ID przekraczały $50 \%$, natomiast połowa $\mathrm{z}$ nich osiągnęła poziom powyżej $90 \%$. W przypadku odmian rzepaku o podwyższonej odporności (Alister i Mendel) najniższe ID obserwowano w temperaturze $13^{\circ} \mathrm{C}$. Jego wartości najczęściej nie przekraczały $10 \%$. Zakres wartości indeksu porażenia wzrastał wraz ze wzrostem temperatury do $16-20^{\circ} \mathrm{C}$, w której ponad połowa uzyskanych wyników przekroczyła wartość $55 \%$. W temperaturze $20-24^{\circ} \mathrm{C}$ zaobserwowano mniejsze porażenie roślin. Połowa uzyskanych wartości ID w tym zakresie temperatury nie przekroczyła 30\% (rys. 3).

Wykresy pudełkowe rozkładu wartości ID wykonane odrębnie dla roślin wrażliwych oraz roślin o podwyższonej odporności w różnych zakresach $\mathrm{pH}$ oraz wilgotności podłoża wykazały różnice pomiędzy badanymi obiektami (rys. 4). W każdym wariancie badanych czynników, rośliny wrażliwe wykazywały znacznie wyższe wartości indeksu porażenia, jednak reakcja na poszczególne czynniki w obu przypadkach była podobna. Największe wartości ID w zależności od pH podłoża obserwowano w zakresie 5,0-5,5. W przypadku roślin wrażliwych na porażenie przez $P$. brassicae ponad połowa uzyskanych wyników przekraczała $80 \%$, podczas gdy wartość indeksu porażenia roślin o podwyższonej odporności najczęściej nie przekraczała 60\% (rys. 4A). 


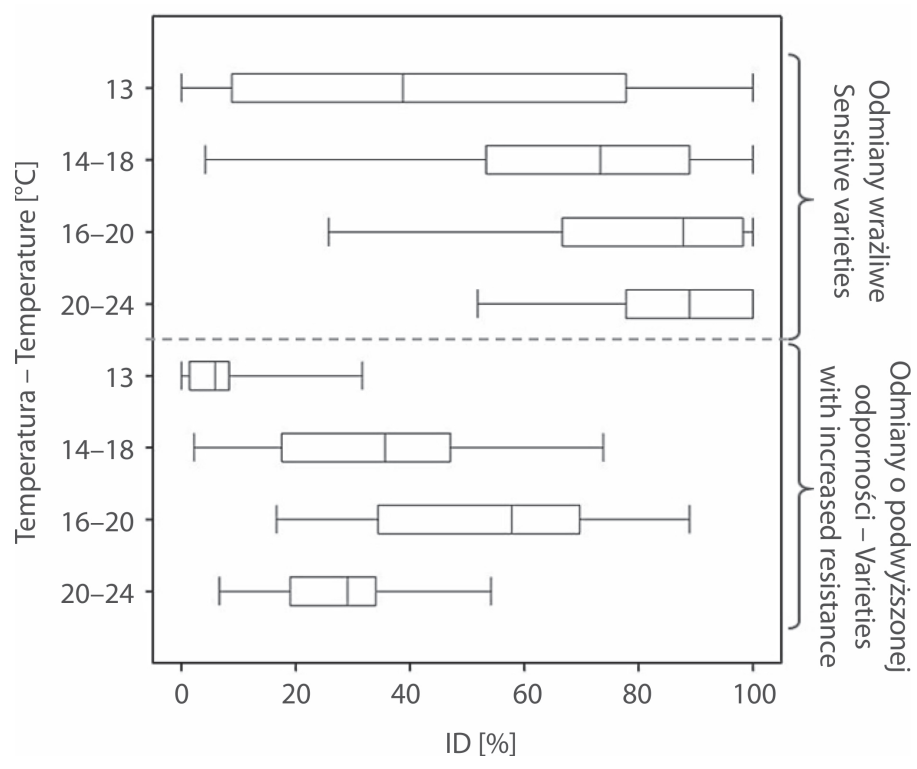

Rys. 3. Rozkład wartości indeksu porażenia (ID) dla roślin wrażliwych oraz roślin o podwyższonej odporności w różnych wariantach temperatury dla obu serii doświadczeń

Fig. 3. Distribution of index disease (ID) values for sensitive plants and plants with increased resistance in various temperature variants for both series of experiments

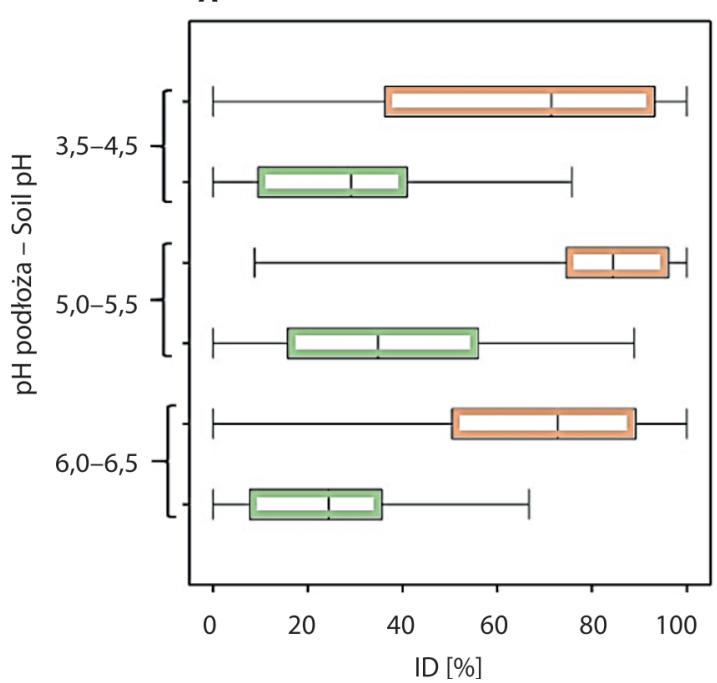

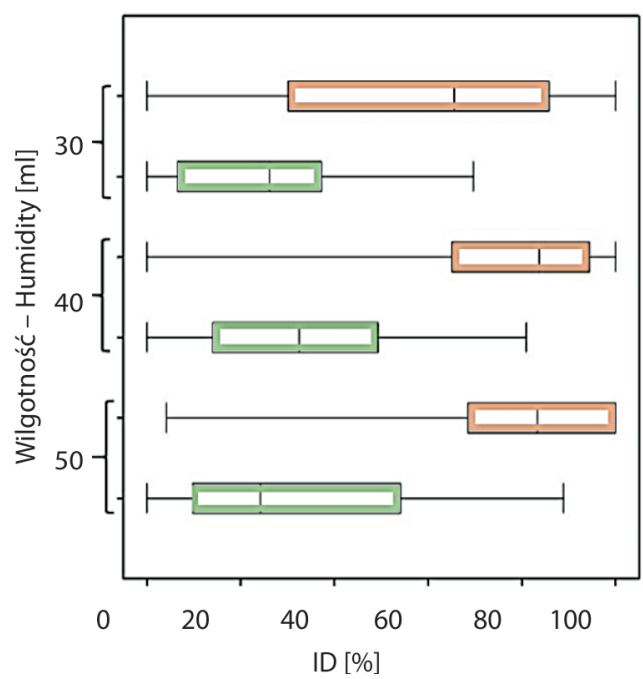

Rys. 4. Rozkład wartości indeksu porażenia (ID) dla roślin wrażliwych (kolor pomarańczowy) oraz roślin o podwyższonej odporności (kolor zielony) w różnych wariantach pH podłoża (A) oraz wilgotności (B) dla obu serii doświadczeń

Fig. 4. Distribution of index disease (ID) values for sensitive plants (orange) and plants with increased resistance (green) in various variants of substrate $\mathrm{pH}(\mathrm{A})$ and humidity $(\mathrm{B})$ for both series of experiments

Analiza wykresu pudełkowego uwzględniającego różne warianty wilgotności podłoża wskazuje, że najwyższe wartości indeksu porażenia roślin zarówno wrażliwych, jak i roślin o podwyższonej odporności wystąpiły w wariantach optymalnego oraz nadmiernego nawadniania roślin (40 i $50 \mathrm{ml}$ ) (rys. 4B).

Wykresy pudełkowe obrazujące rozkład wartości ID w zależności od $\mathrm{pH}$ podłoża oraz wilgotności w różnych zakresach temperatury wskazują, że porażenie roślin najsilniej ograniczała temperatura $13^{\circ} \mathrm{C}$ (rys. 5). Najniższe wartości indeksu porażenia obserwowano przy niskiej temperaturze $\left(13^{\circ} \mathrm{C}\right)$ oraz niedoborze wody $(30 \mathrm{ml})$. W tym wariancie doświadczeń ID najczęściej nie przekraczał wartości 10\% (rys. 5B). Podobne wyniki otrzymano $\mathrm{W}$ kombinacji niskiej temperatury $\left(13^{\circ} \mathrm{C}\right)$ oraz niskiego $\mathrm{pH}$ podłoża 3,5-4,5 (rys. 5A). Natomiast najbardziej stymulująco na porażenie roślin wpływała wysoka temperatura $\left(16-20^{\circ} \mathrm{C}\right.$ oraz $\left.20-24^{\circ} \mathrm{C}\right)$ w połączeniu $\mathrm{z}$ nadmiarem wody $(50 \mathrm{ml}$ ) (rys. 5B) oraz $\mathrm{pH}$ 5,0-5,5 (rys. 5A).

Pomimo braku całkowitej odporności odmian rzepaku, przeprowadzone doświadczenia wykazały istotne różnice pomiędzy reakcją na patogena odmian wrażliwych oraz odmian o podwyższonej odporności. Dlatego tak ważne są badania nad znalezieniem nowych źródeł odporności, które w przyszłości mogłyby umożliwić bardziej efektywną walkę z kiłą kapusty (Diederichsen i wsp. 2014). 
A

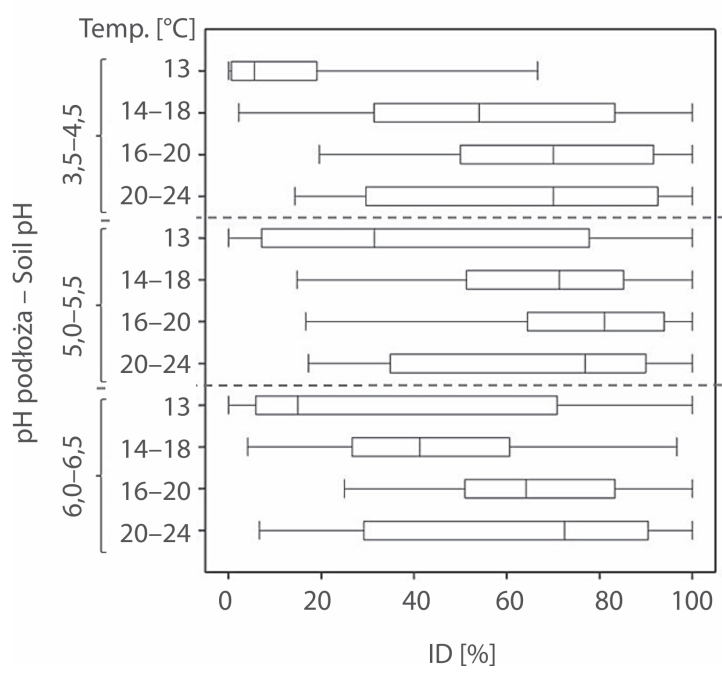

B

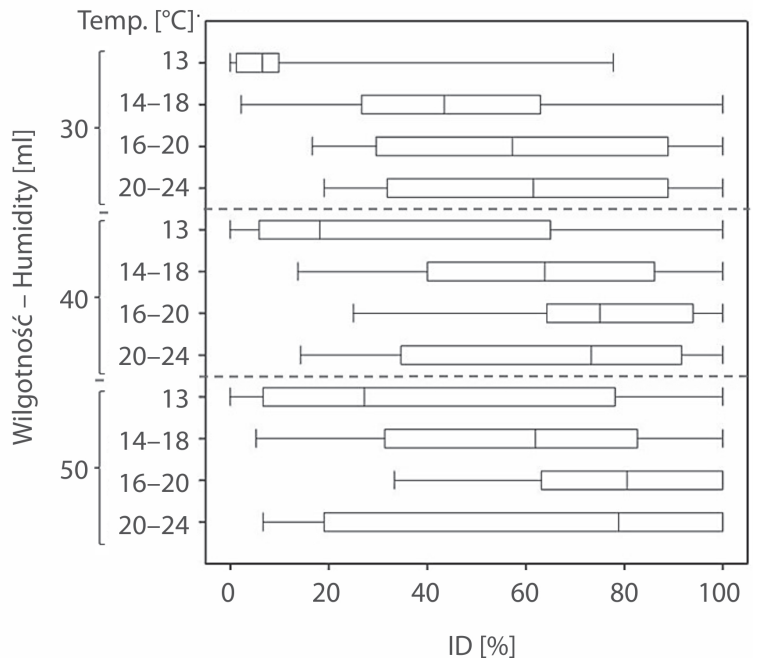

Rys. 5. Rozkład wartości indeksu porażenia (ID) w zależności od pH podłoża (A) oraz wilgotności (B) w różnych zakresach temperatury dla obu serii doświadczeń

Fig. 5. Distribution of index disease (ID) values depending on substrate $\mathrm{pH}(\mathrm{A})$ and humidity (B) in different temperature ranges for both series of experiments

\section{Wnioski / Conclusions}

1. Rozwój P. brassicae najbardziej ograniczało zastosowanie najniższej temperatury $\left(13^{\circ} \mathrm{C}\right)$ oraz niskiej wilgotności podłoża.
2. Temperatura powyżej $16-20^{\circ} \mathrm{C}$ oraz wysoka wilgotność gleby najsilniej stymulowały rozwój patogena.

3. Optymalna dla rozwoju choroby na odmianach wrażliwych była temperatura $20-24^{\circ} \mathrm{C}$, natomiast na odmianach o podwyższonej odporności $16-20^{\circ} \mathrm{C}$.

\section{Literatura / References}

Colhoun J. 1958. Club root disease of crucifers caused by Plasmodiophora brassicae Woronin, a monograph. Phytopathological Paper No 3. Surrey, Commonwealth Mycological Institute, Kew, 108 ss.

Crute I.R., Gray A.R., Crisp P., Buczacki S.T. 1980. Variation in Plasmodiophora brassicae and resistance to clubroot disease in Brassicas and allied crops - a critical review. Plant Breeding Abstracts 50 (2): 91-104.

Diederichsen E., Frauen M., Ludwig-Müller J. 2014. Clubroot disease management challenges from a German perspective. Canadian Journal of Plant Pathology 36 (1): 85-98. DOI: 10.1080/07060661.2013.861871

Dixon G.R. 2009. Plasmodiophora brassicae in its environment. Journal of Plant Growth Regulation 28 (3): 212-228. DOI: 10.1007/ s00344-009-9098-3

Gossen B.D., Adhikari K.K.C., McDonald M.R. 2012. Effects of temperature on infection and subsequent development of clubroot under controlled conditions. Plant Pathology 61 (3): 593-599. DOI: 10.1111/j.1365-3059.2011.02536.x

https://gd.eppo.int/taxon/PLADBR/distribution

Hwang S.F., Ahmed H.U., Zhou Q., Strelkov S.E., Gossen B.D., Peng G., Turnbull G.D. 2011. Influence of cultivar resistance and inoculum density on root hair infection of canola (Brassica napus) by Plasmodiophora brassicae. Plant Pathology 60 (5): $820-829$. DOI: $10.1111 / j .1365-3059.2011 .02457 . x$

Hwang S.F., Ahmed H.U., Zhou Q., Strelkov S.E., Gossen B.D., Peng G., Turnbull G.D. 2012. Assessment of the impact of resistant and susceptible canola on Plasmodiophora brassicae inoculum potential. Plant Pathology 61 (5): 945-952. DOI: 10.1111/j.13653059.2011.02582.x

Karling J.S. 1942. The Plasmodiophorales. 1st ed. J.S. Karling, New York, 144 ss.

Karling J.S. 1968. The Plasmodiophorales. 2nd ed. Hafner Publishing Co. Inc., New York, 256 ss.

Konieczny W. 2012. Kiła opanowała 250 tys. hektarów. Farmer 5: 38-42.

Korbas M., Jajor E. 2013. Kiła kapusty - narastający problem w uprawie rzepaku. Materiały informacyjne. Instytut Ochrony Roślin Państwowy Instytut Badawczy, Poznań, Syngenta, Warszawa, 15 ss.

Korbas M., Jajor E., Budka A. 2009. Clubroot (Plasmodiophora brassicae) - a threat for oilseed rape. Journal of Plant Protection Research 49 (4): 446-451. DOI: 10.2478/v10045-009-0071-8

Palm E.T. 1958. Effect of mineral nutrition on invasiveness of Plasmodiophora brassicae Wor. and the development of clubroot. Dissertation Abstracts 19: 425-426. 
Rennie D.C., Manolii V.P., Cao T., Hwang S.F., Howard R.J., Strelkov S.E. 2011. Direct evidence of surface infestation of seeds and tubers by Plasmodiophora brassicae and quantification of spore load. Plant Pathology 60 (5): 811-819. DOI: 10.1111/j.13653059.2011.02449.x

Řičařová V., Kaczmarek J., Strelkov S.E., Kazda J., Lueders W., Rysanek P., Manolii V., Jędryczka M. 2016. Pathotypes of Plasmodiophora brassicae causing damage to oilseed rape in the Czech Republic and Poland. European Journal of Plant Pathology 145 (3): $559-572$. DOI: $10.1007 / \mathrm{s} 10658-016-0939-1$

Rod J. 1996. Reports - Agent of clubroot of crucifer. Brno, UKZUZ, 37 (Special Issue): 1-45.

Shapiro S.S., Wilk M.B. 1965. An analysis of variance test for normality. Biometrika 52 (3/4): 591-611. DOI: 10.2307/2333709

Strelkov S.E., Tewari J.P., Smith-Degenhardt E. 2006. Characterization of Plasmodiophora brassicae populations from Alberta, Canada. Canadian Journal of Plant Pathology 28 (3): 467-474. DOI: 10.1080/07060660609507321

Vigier B., Chiang M.S., Hume D.J. 1989. Source of resistance to clubroot (Plasmodiophora brassicae Wor.) in triazine-resistant spring canola (rapeseed). Canadian Plant Disease Survey 69 (2): 113-115.

Voorrips R.E. 1996. Production, characterization and interaction of single-spore isolates of Plasmodiophora brassicae. European Journal of Plant Pathology 102 (4): 377-383. DOI: 10.1007/BF01878132

Webster M.A., Dixon G.R. 1991. Calcium, pH and inoculum concentration influencing colonization by Plasmodiophora brassicae. Mycological Research 95 (1): 64-73. DOI: 10.1016/S0953-7562(09)81362-2

Wellman F.L. 1930. Clubroot of crucifers. Technical Bulletin No. 181. United States Department of Agriculture, Washington, D. C., 31 ss. 